\title{
CBFA2T3/GLIS2 Fusion Gene
}

National Cancer Institute

\section{Source}

National Cancer Institute. CBFA2T3/GLIS2 Fusion Gene. NCI Thesaurus. Code C105819.

A fusion gene that results from a chromosomal translocation inv(16)(p13q24) which

fuses either the first 10 or 11 exons of the CBFA2T3 gene with either exon 1 or exon 3 of the GLIS2 gene. This fusion is associated with acute megakaryoblastic leukemia. 